\title{
Seroprevalence and associated risk factors of Toxoplasma gondii infection in yaks (Bos grunniens) on the Qinghai-Tibetan Plateau of China
}

\author{
Tao Sun ${ }^{1,2, a}$, Sajid Ur Rahman ${ }^{1, a}$, Jinzhong Cai ${ }^{3}$, Jiangyong Zeng ${ }^{4}$, Rongsheng $\mathrm{Mi}^{1}$, Yehua Zhang ${ }^{1}$, Haiyan Gong ${ }^{1}$,
} Hongcai Ma ${ }^{4}$, Yan Huang ${ }^{1}$, Xiangan $\operatorname{Han}^{1}$, Quan Zhao ${ }^{2, *}$, and Zhaoguo Chen ${ }^{1}{ }^{*}$

${ }^{1}$ Key Laboratory of Animal Parasitology of Ministry of Agriculture, Laboratory of Quality and Safety Risk Assessment for Animal Products on Biohazards (Shanghai) of Ministry of Agriculture, Shanghai Veterinary Research Institute, Chinese Academy of Agricultural Sciences, Shanghai 200241, PR China

2 Animal Science and Technology College, Jilin Agricultural University, Changchun 130118, Jilin, PR China

${ }^{3}$ Veterinary Research Institute, Qinghai Academy of Animal Sciences and Veterinary Medicine, Qinghai University, State Key Laboratory of Plateau Ecology and Agriculture, Xining 810016, Qinghai, PR China

${ }^{4}$ Tibet Livestock Research Institute, Tibet Academy of Agriculture and Animal Science, Lhasa 850009, Tibet, PR China

Received 26 October 2020, Accepted 4 May 2021, Published online 18 May 2021

\begin{abstract}
Toxoplasma gondii is an intracellular parasite that is extensively prevalent globally. Studies have indicated the presence of $T$. gondii infection in animals in some provinces of China, but little is known about $T$. gondii infection in yaks (Bos grunniens) on the Qinghai-Tibetan Plateau. In the current study, to determine the seroprevalence and associated risk factors of $T$. gondii, a total of 2784 serum samples were collected from 18 different sampling sites in eight counties of the Qinghai and Tibet regions of China from 2018 to 2019. Serum antibodies against T. gondii were detected in 261 yaks (9.38\%) via enzyme-linked immunosorbent assay (ELISA). We found that seroprevalence differed significantly among different counties (ranging from $5.41 \%$ in Gangcha to $19.79 \%$ in Datong), by year in the Tibet Autonomous Region (from $2.34 \%$ in 2018 to $13.24 \%$ in 2019), and by age (from $5.59 \%$ in $0<$ year $\leq 1$ to $11.76 \%$ in year $>7)(p<0.05)$. Climate, geographical conditions, and age are the main factors influencing $T$. gondii infection in yaks in these regions. Therefore, our study provides a data reference for public health and prevention of yak toxoplasmosis.
\end{abstract}

Key words: Toxoplasma gondii, Yak, Seroprevalence, Risk factors, Qinghai-Tibetan Plateau.

Résumé - Séroprévalence et facteurs de risque associés à l'infection par Toxoplasma gondii chez les yaks (Bos grunniens) du plateau Qinghai-Tibet en Chine. Toxoplasma gondii est un parasite intracellulaire largement répandu dans le monde. Des études ont indiqué la présence d'une infection par $T$. gondii chez les animaux dans certaines provinces de Chine, mais on connaît peu l'infection par T. gondii chez les yaks (Bos grunniens) sur le plateau Qinghai-Tibet. Dans la présente étude, pour déterminer la séroprévalence et les facteurs de risque associés de T. gondii, un total de 2784 échantillons de sérum ont été prélevés sur 18 sites d'échantillonnage différents dans huit comtés des régions du Qinghai et du Tibet en Chine entre 2018 et 2019. Des anticorps sériques contre T. gondii ont été détectés par dosage immuno-enzymatique (ELISA) chez 261 yaks $(9,38 \%)$. Nous avons constaté que la séroprévalence différait considérablement entre les différents comtés (allant de 5,41 \% à Gangcha à 19,79\% à Datong), d'une année à l'autre dans la région autonome du Tibet (de 2,34 \% en 2018 à 13,24 \% en 2019), et par âge (de 5,59\% pour les animaux de moins d'un an à $11,76 \%$ pour ceux âgés de plus de 7 ans) $(p<0,05)$. Le climat, les conditions géographiques et l'âge sont les principaux facteurs influençant l'infection à $T$. gondii chez les yaks de ces régions. Par conséquent, notre étude fournit des données de référence pour la santé publique et la prévention de la toxoplasmose du yak.

*Corresponding authors: zhaoguochen@shvri.ac. cn; zhaoquan0825@163.com

${ }^{a}$ These authors contributed equally to this work.

This is an Open Access article distributed under the terms of the Creative Commons Attribution License (https://creativecommons.org/licenses/by/4.0), which permits unrestricted use, distribution, and reproduction in any medium, provided the original work is properly cited. 


\section{Introduction}

Toxoplasma gondii is an obligate intracellular parasite that infects various host species worldwide, including yak (Bos grunniens) [6]. This pathogen can be assimilated by oocystcontaminated vegetables, drinking water, fruits, or by the consumption of undercooked meat contaminated with dormant cysts, as well as by trans-placental tachyzoite transmission [2, $21,22]$. In humans, $T$. gondii infection usually does not show any obvious symptoms; however, in patients with weak immune function or immunodeficiency, such as acquired immunodeficiency syndrome (AIDS) patients, infection can lead to serious diseases including epilepsy, encephalitis, retinitis, and even death with virulent strains of $T$. gondii $[14,25$, 26]. Acute infection is followed by asymptomatic dormant infection when parasites develop in numerous organs, such as the skeletal/cardiac muscles, retina, and brain parenchyma [27]. Dormant infection can reboot in immunocompromised patients, with alteration of dormant bradyzoites into duplicating tachyzoites leading to substantial morbidity and $100 \%$ mortality [20]. Previous studies have shown that $T$. gondii infection during pregnancy can lead to miscarriage, premature birth, birth defects, or intellectual disability [7].

The domestic yak (Bos grunniens) is a long-haired domesticated bovid found throughout the Himalayan region of the Tibetan Plateau, Northern Myanmar, Sichuan, Yunnan, and as far north as Mongolia and Siberia. Yaks live in the cold climates and high plateaus (over $3000 \mathrm{~m}$ ) of China, Bhutan, Nepal, Mongolia, Russia, India and other countries [10, 16]. It has been estimated that about $90 \%$ of the world's yaks live on the Qinghai-Tibetan Plateau in China [16]. Milk, meat, faeces and wool of yaks are closely related to the lives of local residents [10]. Yaks graze freely on the Qinghai-Tibetan Plateau, living with other wild animals and domestic livestock. They also share pasture grass and water with a large number of Plateau pika (Ochotona curzoniae) and Qinghai vole (Microtus fuscus) in the region and these species have been confirmed to carry T. gondii [28]. Rodents and small animals are also intermediate hosts of T. gondii, and carnivores such as the Snow leopard (Panthera uncia), Pallas's cat (Otocolobus manul), Siberian weasels (Mustela sibirica), cats, and dogs prey on them. This leads to multiple settings in which yaks can come into close contact with $T$. gondii oocysts.

Nowadays, serological assays are widely used for the clinical diagnosis of toxoplasmosis and these include the indirect hemagglutination test (IHA), indirect fluorescent antibody test (IFAT), and enzyme-linked immunosorbent assay (ELISA) $[4,23,28]$. Previously, studies have reported that the seroprevalence of T. gondii infection in yaks in the Qinghai-Tibetan Plateau of China is between $2.3 \%$ and $35.1 \%$ [15, 17, 18]. However, the prevalence rate differed depending on geographical location. In remote areas of the plateau, $T$. gondii infection of yaks can cause greater economic losses and threaten other animals and human health.

In order to enrich the information on the prevalence and distribution of $T$. gondii infection in yaks in the Qinghai-Tibet Plateau, sera of yaks were collected between 2018 and 2019 and $T$. gondii antibodies were monitored. Our results demonstrate the dynamic epidemic situation of toxoplasmosis in yaks in the Qinghai-Tibet Plateau, and provide support for control of T. gondii infection in yaks and food safety.

\section{Materials and methods \\ Ethics statement}

The experimental protocol was approved by the ethics committee of Shanghai Veterinary Research Institute, Chinese Academy of Agricultural Sciences, approval number (SHVRI-SZ-201811015-03).

\section{Sampling sites and blood collection}

The blood samples of yaks used in this study were collected from six counties (Wulan, Gangcha, Huangzhong, Guinan, Qilian, and Datong) in Qinghai Province with a latitude of $35^{\circ} 09^{\prime}-38^{\circ} 35^{\prime} \mathrm{N}$, and longitude of $97^{\circ} 01^{\prime}-101^{\circ} 56^{\prime} \mathrm{E}$ (Fig. 1), and two counties (Seni and Nyainrong) in the Tibet Autonomous Region with latitude of $30^{\circ} 31^{\prime}-33^{\circ} 24^{\prime} \mathrm{N}$, and longitude of $91^{\circ} 12^{\prime}-93^{\circ} 56^{\prime} \mathrm{E}$ (Fig. 2). A total of 2784 blood samples were collected from the jugular vein of yaks from 2018 to 2019. Disposable blood collection needles (LuTai, ST1021, Shandong, PR China) and vacuum blood collection tubes (BD-Pharmingen, 367820, USA) were used to collect blood samples. Yak owners were asked to provide information on the age and sex of the animal using a questionnaire. After collection, blood samples were centrifuged at $1500 \times g$ for $15 \mathrm{~min}$ and sera were separated and transferred to $1.5 \mathrm{~mL}$ Eppendorf tubes. The serum samples were stored at $-80{ }^{\circ} \mathrm{C}$ until use.

\section{Detection of $T$. gondii antibodies}

Antibodies for $T$. gondii were determined using a commercial T. gondii IgG enzyme-linked immunosorbent assay (ELISA) Kit (Indical Bioscience, Leipzig, Germany). Both positive and negative control sera were available in the kit. The diluted serum sample (1:100) was incubated for $60 \mathrm{~min}$ at room temperature in the assay well and then washed three times. Then $100 \mu \mathrm{L}$ of conjugate was added to each well and incubated for $30 \mathrm{~min}$ at room temperature. The plate was again washed three times and the chromogenic enzyme substrate was added at a concentration of $100 \mu \mathrm{L}$ and incubated for 10 min at room temperature. A stop solution of $100 \mu \mathrm{L}$ was then added to each well to stop the reaction. Finally, the optical density values (OD) of each well were measured using an ELISA plate reader (Epoch Bio-Tek, Winooski, VT, USA) at $450 \mathrm{~nm}$.

The ratio $(S / P)$ values were calculated according to the following equation:

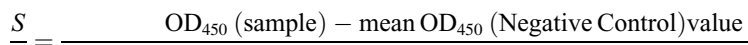
$\bar{P}=\frac{\text { mean } \mathrm{OD}_{450} \text { (Positive Control)value }- \text { mean } \mathrm{OD}_{450} \text { (Negative Control)value }}{\text {. }}$

The serum was considered positive for $T$. gondii if $S /$ $P \geq 0.2$. 


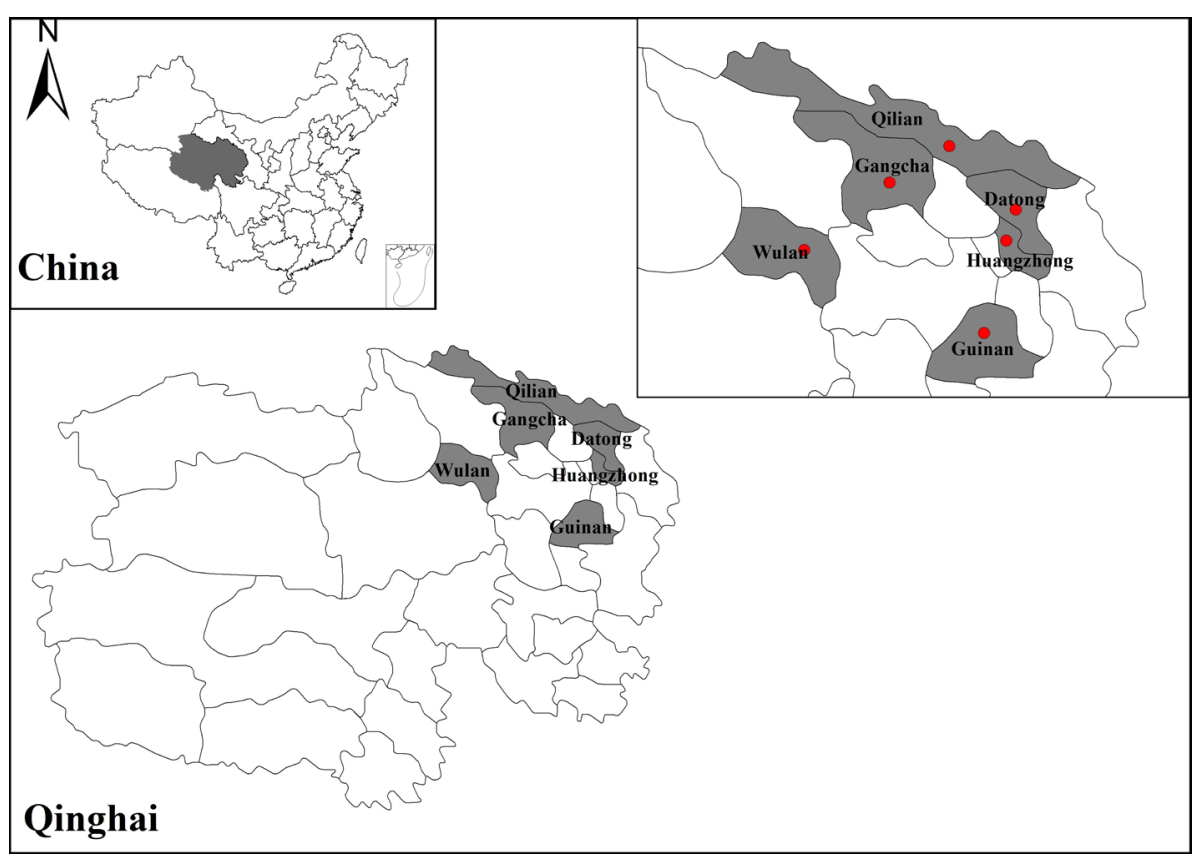

Figure 1. Map of sampling counties in Qinghai in this study. The red dots show the sampling sites.

\section{Statistical analysis}

Statistical analysis was performed using chi-square test with IBM SPSS, v19.0 (SPSS Inc., Chicago, IL, USA). Differences were considered statistically significant when $p<0.05$.

\section{Results}

\section{Seroprevalence of $T$. gondii in yaks of different locations}

Serum samples from 2784 yaks were examined via ELISA, and 261 tested positive for $T$. gondii antibodies, representing a seroprevalence rate of $9.38 \%$. Among them, the prevalence of T. gondii in yaks in Qinghai Province was $8.63 \%(95 / 1101$; 95\% CI, 7.0-10.5), but, in the Tibet Autonomous Region the prevalence rate was $9.86 \%$ (165/1683; 95\% CI, 8.4-11.3). No significant difference was found between province and region $(p>0.05)$.

As shown in Table 1, seroprevalence in different counties ranged from $5.41 \%$ to $19.79 \%$, showing a statistically significant difference $(p<0.05)$. Across 18 sites, ELISA results demonstrated that the highest positive rate occurred in Datong Ranch (19.79\%, 19/96; 95\% CI, 12.4-29.2); however, the lowest prevalence rate was found in Qilian Ranch $(4.19 \%, 7 / 167$; 95\% CI, 1.7-8.5), showing a significant difference $(p<0.05)$ between these sites (Table 1).

\section{Seroprevalence of $T$. gondii in yaks by year}

The seroprevalence of $T$. gondii in yaks of the QinghaiTibet Plateau in 2018 and 2019 was 8.35\% (103/1233; 95\% CI, 6.9-10.0) and $10.19 \%$ (158/1551; 95\% CI, 8.7-11.8), respectively, displaying no significant difference between years $(p>0.05)$.

The prevalence of $T$. gondii in yaks from Qinghai Province in 2018 and 2019 was $8.60 \%(41 / 477 ; 95 \%$ CI, 6.2-11.5) and $8.65 \%$ (54/624; 95\% CI, 5.5-14.1), respectively, with no significant difference $(p>0.05)$. However, in the Tibet Autonomous Region, the prevalence rates were $8.20 \%$ (62/756; 95\% CI, 6.410.4) and $11.22 \%$ (104/927; 95\% CI, 9.3-13.4), in 2018 and 2019, respectively which shows a significant difference between years $(p<0.05)$.

Positive rates at different sampling sites in Qinghai ranged from $0 \%(0 / 11)$ to $19.79 \%(19 / 96)$ in 2018 and from $7.54 \%$ $(15 / 199)$ to $12.20 \%(5 / 41)$ in 2019 , whereas, in Tibet, positivity rates ranged from $6.09 \%(7 / 115)$ to $12.34 \%(19 / 154)$ in 2018 and from $5.00 \%(5 / 100)$ to $15.82 \%(25 / 158)$ in 2019 . Four sampling sites were sampled in 2018 and 2019, showing positive rates of $3.66 \%$ and $8.56 \%$ in Laozhaxi Ranch, $11.72 \%$ and 9.18\% in Gaque Ranch, 9.04\% and $14.38 \%$ in Yumaoxiong village, but $2.34 \%$ and $13.24 \%$ in Payu village, showing highly significant differences $(p<0.01)$ (Table 2$)$.

\section{Seroprevalence of $\boldsymbol{T}$. gondii in yaks by sex}

The data in Table 3 show that the positive rates of $T$. gondii in male and female yaks of the Qinghai-Tibetan Plateau were $8.71 \%(89 / 1022 ; 95 \% \mathrm{CI}, 4.6-7.0)$ and $9.76 \%$ (172/1762; $95 \%$ CI, 8.4-11.2), respectively, which showed no significant difference between the sexes $(p>0.05)$. The positive rates of T. gondii in male and female yaks in Qinghai Province were 7.13\% (35/505; 95\% CI, 4.9-9.5) and 9.90\% (59/596; 95\% CI, 7.6-12.6), respectively. In the Tibet Autonomous Region, the percentages were $10.25 \%(53 / 517 ; 95 \% \mathrm{CI}, 7.8-13.2)$ and $9.69 \%$ (113/1166; 95\% CI, 8.1-11.5), respectively, with no significant difference between the sexes $(p>0.05)$ (Table 3$)$. 


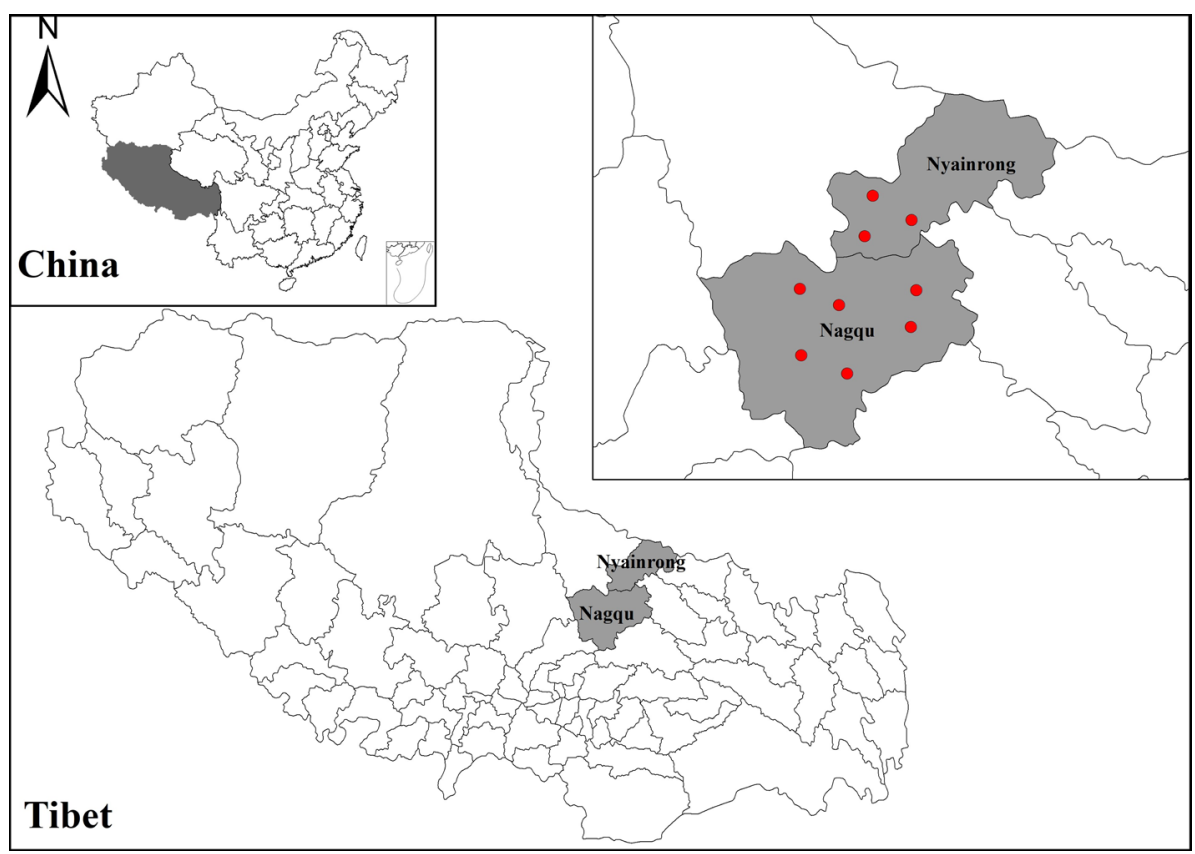

Figure 2. Map of sampling counties in Tibet in this study. The red dots show the sampling sites.

Table 1. Prevalence of $T$. gondii in yaks in different provinces, counties and sampling sites on the Qinghai-Tibetan Plateau.

\begin{tabular}{|c|c|c|c|c|c|c|}
\hline Provinces & Counties & $\begin{array}{c}\text { Positive rates\% } \\
\text { (No. positive/No. samples) }\end{array}$ & $95 \% \mathrm{CI}$ & Sampling sites & $\begin{array}{c}\text { Positive rates } \% \\
\text { (No. positive/No. samples) }\end{array}$ & $95 \% \mathrm{CI}$ \\
\hline \multirow[t]{10}{*}{ Qinghai } & Datong & $19.79(19 / 96)^{\mathrm{a}}$ & $12.4-29.2$ & Datong Ranch & $19.79(19 / 96)^{\mathrm{a}}$ & $12.4-29.2$ \\
\hline & Gangcha & $5.41(4 / 74)^{\mathrm{bc}}$ & $1.5-13.3$ & Qingqingcao Ranch & $5.41(4 / 74)^{\mathrm{de}}$ & $1.5-13.3$ \\
\hline & Guinan & $7.06(19 / 269)^{\mathrm{bc}}$ & $4.3-10.8$ & Laozhaxi Ranch & $7.06(19 / 269)^{\mathrm{de}}$ & $4.3-10.8$ \\
\hline & Huangzhong & $14.77(13 / 88)^{\mathrm{ab}}$ & $9.1-23.9$ & Slaughter houses & $17.02(8 / 47)^{\mathrm{abc}}$ & $7.7-30.8$ \\
\hline & & & & Fengtai Ranch & $12.20(5 / 41)^{\mathrm{abcd}}$ & $4.3-12.1$ \\
\hline & Qilian & $6.01(22 / 366)^{\mathrm{c}}$ & $3.8-9.0$ & Qilain Ranch & $4.19(7 / 167)^{\mathrm{e}}$ & $1.7-8.5$ \\
\hline & & & & Warinai Ranch & $7.54(15 / 199)^{\mathrm{de}}$ & $9.3-13.4$ \\
\hline & Wulan & $8.65(18 / 208)^{\mathrm{bc}}$ & $5.2-13.3$ & Chaidamu Ranch & $0.00(0 / 11)^{\text {abcde }}$ & $0.0-28.5$ \\
\hline & & & & Tongpu Ranch & $9.14(18 / 197)^{\text {bcde }}$ & $5.0-13.5$ \\
\hline & Subtotal & $8.63(95 / 1101)$ & $7.0-10.5$ & & $8.63(95 / 1101)$ & $7.0-10.5$ \\
\hline \multirow[t]{10}{*}{ Tibet } & Seni & $9.98(80 / 802)^{\mathrm{b}}$ & $8.0-12.3$ & Dasa Village & $8.07(13 / 161)^{\text {cde }}$ & $4.4-13.4$ \\
\hline & & & & Gaerde Ranch & $9.65(11 / 114)^{b c d e}$ & $4.9-16.6$ \\
\hline & & & & Maqing Village & $12.34(19 / 154)^{\mathrm{abcd}}$ & $7.6-18.6$ \\
\hline & & & & Mufa Ranch & $5.00(5 / 100)^{\mathrm{de}}$ & $1.6-11.3$ \\
\hline & & & & Namaqiegong Village & $15.82(25 / 158)^{\mathrm{ab}}$ & $10.5-22.5$ \\
\hline & & & & Naqu Ranch & $6.09(7 / 115)^{\mathrm{de}}$ & $2.5-12.1$ \\
\hline & Nyainrong & $9.76(86 / 881)^{b}$ & $7.9-11.9$ & Gaque Ranch & $10.62(24 / 226)^{\mathrm{bcd}}$ & $1.8-4.0$ \\
\hline & & & & Payu Village & $7.17(22 / 307)^{\mathrm{de}}$ & $4.6-10.7$ \\
\hline & & & & Yumaoxiong Village & $11.49(40 / 348)^{\mathrm{bcd}}$ & $8.3-15.3$ \\
\hline & Subtotal & $9.86(166 / 1683)$ & $8.5-11.4$ & & $9.86(166 / 1683)$ & $8.5-11.4$ \\
\hline Total & & $9.38(261 / 2784)$ & $8.3-10.5$ & & $9.38(261 / 2784)$ & $8.3-10.5$ \\
\hline
\end{tabular}

Note: The same lowercase letters within columns represent no significant differences between groups $(p>0.05)$ and different lowercase letters within columns represent significant differences between groups $(p<0.05)$.

\section{Seroprevalence of $T$. gondii in yaks by age}

In this study, the yaks were divided into five age groups. The highest positive rate of $T$. gondii in yaks was found at the age of $>7$ years old $(11.76 \%, 28 / 238 ; 95 \%$ CI, 8.0-16.6). However, a relatively low prevalence rate was found at $0<$ year $\leq 1(5.59 \%, 16 / 286 ; 95 \%$ CI, 3.2-8.9), which showed a significant difference $(p<0.05)$ at different ages. In Qinghai Province, the highest positive rate was found at the age of $5<$ year $\leq 7$ (17.88\%, 27/151; 95\% CI, 12.1-24.9), and the lowest positive rate was found at $0<$ year $\leq 1(4.71 \%, 12 /$ 255 ; 95\% CI, 2.5-8.1), showing a significant difference $(p<0.05)$. The highest positive rate of $T$. gondii in yaks in the Tibet Autonomous Region was found at the age of 
Table 2. Seroprevalence of T. gondii infection by year in yaks on the Qinghai-Tibetan Plateau.

\begin{tabular}{|c|c|c|c|c|c|c|c|c|}
\hline \multirow[t]{2}{*}{ Provinces } & \multirow[t]{2}{*}{ Counties } & \multirow[t]{2}{*}{ Sampling sites } & \multicolumn{2}{|l|}{2018} & \multicolumn{2}{|l|}{2019} & \multicolumn{2}{|c|}{ Average } \\
\hline & & & $\begin{array}{c}\text { Positive rates\% } \\
\text { (No. positive/ } \\
\text { No. samples) }\end{array}$ & $95 \% \mathrm{CI}$ & $\begin{array}{l}\text { Positive rates\% } \\
\text { (No. positive/ } \\
\text { No. samples) }\end{array}$ & $95 \% \mathrm{CI}$ & $\begin{array}{l}\text { Positive rates } \% \\
\text { (No. positive/ } \\
\text { No. samples) }\end{array}$ & $95 \% \mathrm{CI}$ \\
\hline \multirow[t]{10}{*}{ Qinghai } & Datong & Datong Ranch & $19.79(19 / 96)^{\mathrm{a}}$ & $12.4-29.2$ & - & - & $19.79(19 / 96)^{\mathrm{a}}$ & $12.4-29.2$ \\
\hline & Gangcha & $\begin{array}{l}\text { Qingqingcao } \\
\text { Ranch }\end{array}$ & $5.41(4 / 74)^{\mathrm{cde}}$ & $1.5-13.3$ & - & - & $5.41(4 / 74)^{b d}$ & $1.5-13.3$ \\
\hline & Guinan & Laozhaxi Ranch & $3.66(3 / 82)^{\mathrm{de}}$ & $0.8-10.3$ & $8.56(16 / 187)^{\mathrm{bcd}}$ & $4.1-26.2$ & $7.06(19 / 269)^{\mathrm{cd}}$ & $4.3-10.8$ \\
\hline & Huangzhong & Slaughterhouses & $17.02(8 / 47)^{\mathrm{ab}}$ & $7.7-30.8$ & - & - & $14.77(13 / 88)^{\mathrm{ab}}$ & $8.1-23.9$ \\
\hline & & Fengtai Ranch & - & - & $12.20(5 / 41)^{\mathrm{abcd}}$ & $4.3-12.1$ & & \\
\hline & Qilian & Qilain Ranch & $4.19(7 / 167)^{\mathrm{de}}$ & $1.7-8.5$ & - & - & $6.01(22 / 366)^{\mathrm{d}}$ & $3.8-9.0$ \\
\hline & & Warinai Ranch & - & - & $7.54(15 / 199)^{\mathrm{cd}}$ & $9.3-13.4$ & & \\
\hline & Wulan & $\begin{array}{l}\text { Chaidamu } \\
\text { Ranch }\end{array}$ & $0.00(0 / 11)^{\text {abcde }}$ & $0.0-28.5$ & - & - & $8.65(18 / 208)^{\mathrm{bcd}}$ & $5.2-13.3$ \\
\hline & & Tongpu Ranch & - & - & $9.14(18 / 197)^{\mathrm{abcd}}$ & $5.0-13.5$ & & \\
\hline & Total & & $8.60(41 / 477)$ & $6.2-11.5$ & $8.65(54 / 624)$ & $5.5-14.1$ & $8.63(95 / 1101)$ & $7.0-10.5$ \\
\hline \multirow[t]{10}{*}{ Tibet } & Seni & Dasa Village & - & - & $8.07(13 / 161)^{\mathrm{bcd}}$ & $4.4-13.4$ & $9.98(80 / 802)^{\mathrm{bc}}$ & $8.0-12.3$ \\
\hline & & Gaerde Ranch & - & - & $9.65(11 / 114)^{\mathrm{abcd}}$ & $4.9-16.6$ & & \\
\hline & & Maqing Village & $12.34(19 / 154)^{\mathrm{abc}}$ & $7.6-18.6$ & ${ }^{2}$ & - & & \\
\hline & & Mufa Ranch & - & - & $5.00(5 / 100)^{\mathrm{d}}$ & $1.6-11.3$ & & \\
\hline & & $\begin{array}{c}\text { Namaqiegong } \\
\text { Village }\end{array}$ & - & - & $15.82(25 / 158)^{\mathrm{a}}$ & $10.5-22.5$ & & \\
\hline & & Naqu Ranch & $6.09(7 / 115)^{\mathrm{cde}}$ & $2.5-12.1$ & - & - & & \\
\hline & Nyainrong & Gaque Ranch & $11.72(15 / 128)^{\mathrm{abc}}$ & $6.7-18.6$ & $9.18(9 / 98)^{\mathrm{abcd}}$ & $4.3-16.7$ & $9.76(86 / 881)^{\mathrm{bc}}$ & 7.9-11.9 \\
\hline & & Payu Village & $2.34(4 / 171)^{\mathrm{e}}$ & $0.6-5.9$ & $13.24(18 / 136)^{\mathrm{abc}}$ & $8.0-20.1$ & & \\
\hline & & $\begin{array}{c}\text { Yumaoxiong } \\
\text { Village }\end{array}$ & $9.04(17 / 188)^{\mathrm{bcd}}$ & $5.4-14.1$ & $14.38(23 / 160)^{\mathrm{ab}}$ & $9.3-20.8$ & & \\
\hline & Total & & $8.20(62 / 756)$ & $6.4-10.4$ & $11.22(104 / 927)$ & $9.3-13.4$ & $9.86(166 / 1683)$ & $8.5-11.4$ \\
\hline $\begin{array}{l}\text { Qinghai and } \\
\text { Tibet }\end{array}$ & & & $8.35(103 / 1233)$ & $6.9-10.0$ & $10.19(158 / 1551)$ & $8.7-11.8$ & $9.38(261 / 2784)$ & $8.3-10.5$ \\
\hline
\end{tabular}

Note: The same lowercase letters within columns represent no significant differences between groups $(p>0.05)$ and different lowercase letters within columns represent significant differences between groups $(p<0.05)$.

$0<$ year $\leq 1(12.90 \%, 4 / 31 ; 95 \% \mathrm{CI}, 3.6-29.8)$, and the lowest rate was observed at $3<$ year $\leq 5(8.88 \%, 49 / 552 ; 95 \% \mathrm{CI}$, 6.6-11.6). There was no significant difference found among different ages of yaks in the region $(p>0.05)$ (Table 4$)$.

\section{Discussion}

To date, there are insufficient data on yak toxoplasmosis, and there are only a limited number of reports on yak toxoplasmosis from China. As a globally important zoonotic parasite, T. gondii was first isolated from humans in the $1930 \mathrm{~s}$ and is estimated to have infected $30 \%$ of the world's population [24]. The transmission of the parasite to humans can occur through ingestion of raw or inadequately cooked infected meat from domestic animals or through consumption of animal products containing $T$. gondii cysts. In China, especially on the Qinghai-Tibetan Plateau, T. gondii infection in yaks is an important risk factor for the local population. Therefore, studying the prevalence of $T$. gondii in yaks is an important step to control foodborne toxoplasmosis in these regions.

Evaluation by serological tests, especially ELISA, is a convenient and efficient method to detect $T$. gondii infection in animals [9]. In the present study, the overall prevalence of T. gondii was found to be $9.38 \%$, which is slightly lower than in the previous study [15]. Dubey reported in 2008 that the estimated overall global prevalence of $T$. gondii in cattle using different detection methods was $14.96 \%$ (8 286/55 377) [7]. According to survey results from 2000 to 2017, the overall prevalence of $T$. gondii in cattle in China was $10.6 \%$ (2 781/ 26 210), with total prevalence in yaks of $13.5 \%$ (1221/9042) [5]. Compared to other countries, the prevalence of $T$. gondii in yaks on the plateau was lower than in cattle in Brazil $(54.4 \%, 272 / 500)$ and Estonia $(18.6 \%, 743 / 3991)$ [3, 12]; however, slightly higher than $7.3 \%(31 / 422)$ in cattle in Japan and $3.2 \%(127 / 4033)$ in Poland $[11,19]$. The reason for this difference may be related to differences in detection methods, climate, environment and geographical factors, as well as effective pest control measures and level of breeding management.

The positive prevalence rate of $T$. gondii in yaks in Qinghai Province and the Tibet Autonomous Region showed no significant difference $(p>0.05)$. Among the eight counties, Datong County had the highest positive rate compared to Gangcha County, which showed no significant difference $(p<0.05)$. At the 18 sampling sites, all showed toxoplasma antibodies, except one. In these counties, the prevalence rate ranged from $0.0 \%$ to $19.4 \%$, showing a significant difference $(p<0.05)$ between sampling sites. The difference in positive prevalence rates may be due to pasture management, climate, and environmental conditions associated with these areas as risk factors. The altitude of the different sampling sites also affects the 
Table 3. Seroprevalence of T. gondii infection by sex in yaks on the Qinghai-Tibetan Plateau in 2018 and 2019.

\begin{tabular}{|c|c|c|c|c|c|c|c|c|c|c|c|c|c|c|c|c|c|c|}
\hline \multirow{3}{*}{ Sex } & \multicolumn{6}{|c|}{ Qinghai } & \multicolumn{6}{|c|}{ Tibet } & \multicolumn{6}{|c|}{ Qinghai and Tibet } \\
\hline & \multicolumn{2}{|l|}{2018} & \multicolumn{2}{|l|}{2019} & \multicolumn{2}{|l|}{ Total } & \multicolumn{2}{|l|}{2018} & \multicolumn{2}{|l|}{2019} & \multicolumn{2}{|l|}{ Total } & \multicolumn{2}{|l|}{2018} & \multicolumn{2}{|l|}{2019} & \multicolumn{2}{|l|}{ Total } \\
\hline & $\begin{array}{c}\text { Positive rates \% } \\
\text { (No. positive/ } \\
\text { No. samples) }\end{array}$ & $95 \% \mathrm{CI}$ & $\begin{array}{l}\text { Positive rates \% } \\
\text { (No. positive/ } \\
\text { No. samples) }\end{array}$ & $95 \%$ CI & $\begin{array}{c}\text { Positive rates \% } \\
\text { (No. positive/ } \\
\text { No. samples) }\end{array}$ & $95 \% \mathrm{CI}$ & $\begin{array}{l}\text { Positive rates \% } \\
\text { (No. positive/ } \\
\text { No. samples) }\end{array}$ & $95 \% \mathrm{CI}$ & $\begin{array}{c}\text { Positive rates \% } \\
\text { (No. positive/ } \\
\text { No. samples) }\end{array}$ & $95 \% \mathrm{CI}$ & $\begin{array}{l}\text { Positive rates \% } \\
\text { (No. positive/ } \\
\text { No. samples) }\end{array}$ & $95 \% \mathrm{CI}$ & $\begin{array}{c}\text { Positive rates \% } \\
\text { (No. positive / } \\
\text { No. sample) }\end{array}$ & $95 \%$ CI & $\begin{array}{c}\text { Positive rates \% } \\
\text { (No. positive / } \\
\text { No. sample) }\end{array}$ & $95 \% \mathrm{CI}$ & $\begin{array}{c}\text { Positive rates \% } \\
\text { (No. positive / } \\
\text { No. sample) }\end{array}$ & $695 \% \mathrm{CI}$ \\
\hline & $6.15(15 / 244)^{a}$ & -9.9 & $8.05(21 / 261)^{\mathrm{a}}$ & & $7.13(35 / 505)^{\mathrm{a}}$ & .5 & $8.57(12 / 140)^{\mathrm{a}}$ & .5 & $1377)^{\mathrm{a}}$ & & $10.25(53 / 517)^{\mathrm{a}}$ & & $7.03(27 / 384)^{\mathrm{a}}$ & & $9.72(62 / 638)^{\mathrm{a}}$ & -12.3 & $8.71(89 / 1022)^{\mathrm{a}}$ & .0 \\
\hline male & $11.16(26 / 233)^{\mathrm{a}}$ & 5.9 & $9.09(33 / 363)^{\mathrm{a}}$ & -12.5 & $9.90(59 / 596)^{\mathrm{a}}$ & & $8.12(50 / 616)^{\mathrm{a}}$ & -10.6 & $11.45(63 / 550)^{\mathrm{a}}$ & -14.5 & $9.69(113 / 1166)^{\mathrm{a}}$ & -11.5 & $8.95(76 / 849)^{\mathrm{a}}$ & & $10.51(96 / 913)^{\mathrm{a}}$ & $6-12.7$ & $9.76(172 / 1762)^{a}$ & $8.4-11.2$ \\
\hline tal & $8.60(41 / 477)$ & & $8.65(54 / 624)$ & 1.1 & $8.63(95 / 1101)$ & 0.5 & $8.20(62 / 756)$ & 1-10.4 & (104/927) & -13.4 & $36(166 / 1683)$ & -11.4 & 1233) & & 1 & & $38(261 / 2784)$ & \\
\hline
\end{tabular}

Note: The same lowercase letters within columns represent no significant differences between groups $(p>0.05)$ and different lowercase letters within columns represent significant differences between groups $(p<0.05)$.

Table 4. Seroprevalence of T. gondii infection by age in yaks on the Qinghai-Tibetan Plateau in 2018 and 2019.

\begin{tabular}{|c|c|c|c|c|c|c|c|c|c|c|c|c|c|c|c|c|c|c|}
\hline \multirow[t]{3}{*}{$\overline{\text { Ages }}$} & \multicolumn{6}{|c|}{ Qinghai } & \multicolumn{6}{|c|}{ Tibet } & \multicolumn{6}{|c|}{ Qinghai and Tibet } \\
\hline & \multicolumn{2}{|l|}{2018} & \multicolumn{2}{|l|}{2019} & \multicolumn{2}{|l|}{ Subtotal } & \multicolumn{2}{|l|}{2018} & \multicolumn{2}{|l|}{2019} & \multicolumn{2}{|l|}{ Subtotal } & \multicolumn{2}{|l|}{2018} & \multicolumn{2}{|l|}{2019} & \multicolumn{2}{|c|}{ Subtotal } \\
\hline & $\begin{array}{l}\text { Positive rates \% } \\
\text { (No. positive/ } \\
\text { No. samples) }\end{array}$ & $95 \% \mathrm{CI}$ & $\begin{array}{c}\text { Positive rates \% } \\
\text { (No. positive/ } \\
\text { No. samples) }\end{array}$ & $95 \%$ CI & $\begin{array}{l}\text { Positive rates \% } \\
\text { (No. positive/ } \\
\text { No. samples) }\end{array}$ & $95 \% \mathrm{CI}$ & $\begin{array}{c}\text { Positive rates \% } \\
\text { (No. positive/ } \\
\text { No. samples) }\end{array}$ & $95 \% \mathrm{CI}$ & $\begin{array}{l}\text { Positive rates \% } \\
\text { (No. positive/ } \\
\text { No. samples) }\end{array}$ & $95 \% \mathrm{CI}$ & $\begin{array}{l}\text { Positive rates \% } \\
\text { (No. positive/ } \\
\text { No. samples) }\end{array}$ & $95 \%$ CI & $\begin{array}{c}\text { Positive rates \% } \\
\text { (No. positive / } \\
\text { No. sample) }\end{array}$ & $95 \% \mathrm{CI}$ & $\begin{array}{l}\text { Positive rates \% } \\
\text { (No. positive / } \\
\text { No. sample) }\end{array}$ & $95 \% \mathrm{CI}$ & $\begin{array}{c}\text { Positive rates \% } \\
\text { (No. positive / } \\
\text { No. sample) }\end{array}$ & $95 \% \mathrm{CI}$ \\
\hline $0<$ year $\leq 1$ & $6.61(8 / 121)^{\mathrm{bc}}$ & $2.9-12.6$ & $2.99(4 / 134)^{c}$ & $0.8-7.5$ & $4.71(12 / 255)^{\mathrm{b}}$ & $2.5-8.1$ & $5.00(1 / 20)^{\mathrm{a}}$ & $0.1-24.9$ & $27.27(3 / 11)^{\mathrm{a}}$ & $6.0-61.0$ & $12.90(4 / 31)^{\mathrm{a}}$ & $3.6-29.8$ & $6.38(9 / 141)^{\mathrm{a}}$ & $3.0-11.8$ & $4.83(7 / 145)^{\mathrm{c}}$ & $2.0-9.7$ & $5.59(16 / 286)^{\mathrm{b}}$ & $3.2-8.9$ \\
\hline $1<$ year $\leq 3$ & $7.76(9 / 116)^{\mathrm{bc}}$ & $3.6-14.2$ & $7.76(17 / 219)^{\mathrm{bc}}$ & $4.6-12.1$ & $7.76(26 / 335)^{\mathrm{b}}$ & $5.1-11.2$ & $9.59(14 / 146)^{\mathrm{a}}$ & $5.3-15.6$ & $11.76(26 / 221)^{\mathrm{a}}$ & $7.8-16.8$ & $10.90(40 / 367)^{\mathrm{a}} 7$ & $7.9-14.5$ & $8.78(23 / 262)^{\mathrm{a}}$ & $5.7-12.9$ & $9.77(43 / 440)^{\mathrm{abc}}$ & $7.2-12.9$ & $9.40(66 / 702)^{\mathrm{a}}$ & $7.4-11.8$ \\
\hline $3<$ year $\leq 5$ & $3.42(4 / 117)^{\mathrm{c}}$ & $0.9-8.5$ & $8.61(13 / 151)^{\mathrm{b}}$ & $4.7-14.3$ & $6.34(17 / 268)^{\mathrm{b}}$ & $3.7-10.0$ & $7.98(19 / 238)^{\mathrm{a}}$ & $4.9-12.2$ & $9.55(30 / 314)^{\mathrm{a}}$ & 6.54-13.4 & $8.88(49 / 552)^{a}$ & $6.6-11.6$ & $6.48(23 / 355)^{\mathrm{a}}$ & $4.2-9.6$ & $9.25(43 / 465)^{\mathrm{bc}}$ & $6.8-12.3$ & $8.05(66 / 820)^{\text {ab }}$ & $6.3-10.1$ \\
\hline $5<$ year $\leq 7$ & $17.78(16 / 90)^{\mathrm{a}}$ & $10.5-27.3$ & $18.03(11 / 61)^{\mathrm{a}}$ & $9.4-30.0$ & $17.88(27 / 151)^{\mathrm{a}}$ & $12.1-24.9$ & $6.81(19 / 279)^{\mathrm{a}}$ & 4.2-10.4 & $12.66(39 / 308)^{\mathrm{a}}$ & $9.2-16.9$ & $9.88(58 / 587)^{\mathrm{a}}$ & $7.6-12.6$ & $9.49(35 / 369)^{\mathrm{a}}$ & $6.7-12.9$ & $13.55(50 / 369)^{\mathrm{a}}$ & $10.2-17.5$ & $11.52(85 / 738)^{\mathrm{a}}$ & $9.3-14.0$ \\
\hline year $>7$ & $12.12(4 / 33)^{\mathrm{ab}}$ & $3.4-28.2$ & $15.25(9 / 59)^{\mathrm{ab}}$ & $7.2-27.0$ & $14.13(13 / 92)^{\mathrm{a}}$ & $4.7-14.3$ & $12.33(9 / 73)^{\mathrm{a}}$ & $5.8-22.1$ & $8.22(6 / 73)^{\mathrm{a}}$ & $3.1-17.0$ & $10.27(15 / 146)^{\mathrm{a}} 5$ & $5.9-16.4$ & $12.26(13 / 106)^{\mathrm{a}}$ & $6.7-20.0$ & $11.36(15 / 132)^{\mathrm{ab}}$ & $6.5-18.1$ & $11.76(28 / 238)^{\mathrm{a}}$ & $8.0-16.6$ \\
\hline Total & $8.60(41 / 477)$ & $6.2-11.5$ & $8.65(54 / 624)$ & $6.6-11.1$ & $8.63(95 / 1101)$ & $7.0-10.5$ & $8.20(62 / 756)$ & $6.4-10.4$ & $11.22(103 / 927)$ & $9.3-13.4$ & $9.86(166 / 1683) 8$ & $8.5-11.4$ & $8.35(103 / 1233)$ & $6.9-10.0$ & $10.19(158 / 1551)$ & $8.7-11.8$ & $9.38(261 / 2784)$ & $8.3-10.5$ \\
\hline
\end{tabular}

Note: The same lowercase letters within columns represent no significant differences between groups $(p>0.05)$ and different lowercase letters within columns represent significant differences between groups $(p<0.05)$. 
infection rate of the parasite: for example, the positive rate of $T$. gondii infection was higher in yaks at Maqing Village (4480 $\mathrm{m}$ above sea level) and Namaqiegong Village (4530 m above sea level) than that at Payu Village ( $4970 \mathrm{~m}$ above sea level). Some studies have shown that Toxoplasma infections are often high in areas of the world with hot, humid climates and lower altitudes because the oocysts survive better in these environments $[1,6]$.

In the present study between 2018 and 2019, the seroprevalence of $T$. gondii on both the plateau and in Qinghai Province showed no significant difference $(p>0.05)$ between years. However, in Tibet, the prevalence rate showed a significant difference between 2018 and $2019(p<0.05)$. A previous study conducted by Li et al. [15] in 2012 and 2013 reported seroprevalence of $20.5 \%(142 / 693)$ and $26.7 \%$ (129/484) in yaks on the plateau. The discrepancies between the present and previous studies may be due to $T$. gondii detection methods or sampling locations. In addition, we found that of the four sampling sites in these two years, three sites had higher positive rates in 2019 compared to 2018, although the difference was not significant $(p>0.05)$. A possible reason for this could be the collection of samples in two different seasons, as in 2018 the samples were collected in winter, while in 2019 the samples were collected in summer. Yaks can become infected through contact with contaminated grass, water or soil contaminated with $T$. gondii oocysts. In our study, the positive rates of samples collected in summer were higher than those collected in winter, suggesting that fresh grass used as yak feed may contain T. gondii oocysts and the moist environment is favourable for oocyst survival. In a previous study, it was reported that $T$. gondii infection tends to be in warm and humid environments due to different climatic and geographical conditions, which was consistent with our findings [13].

In terms of sex, we found that the $T$. gondii positive rate was higher in female yaks than in males, but the difference was not significant $(p>0.05)$. Previous studies have concluded that sex is not necessarily a risk factor associated with $T$. gondii infection [25]. These findings are consistent with our current results, indicating that $T$. gondii infection does not have a particular sex specificity.

We found that age was an important factor influencing T. gondii infection in yaks. In this study, significant differences in the prevalence of $T$. gondii were observed between different age groups of yaks $(p<0.05)$. Our results showed that, as the age of yaks increases, the prevalence of $T$. gondii gradually increased. As adult yaks graze freely, they are more likely to be exposed to food and water contaminated with $T$. gondii oocysts. Previous studies also reported that the seroprevalence of $T$. gondii increased with the age of the yaks [18].

In Qinghai and Tibet, yaks are the main source of meat and milk for the local population. However, when raw yak meat and their internal organs, in which $T$. gondii cysts are present, are eaten by local cats and other Felidae animals, they can become infected and T. gondii oocysts are produced and shed. The Yangtze River and Yellow River in China originate from the Qinghai-Tibetan Plateau. Toxoplasma gondii oocysts can survive in water and can be transported to downstream areas and even the ocean via freshwater rivers, posing a great threat to humans and animals living along riverbanks [8]. If T. gondii infection from these sources is not effectively controlled, it will become a public health risk factor in downstream areas and affect the prevention and control of $T$. gondii infection in these areas. Therefore, our study provides basic data for local and downstream public health prevention of zoonotic toxoplasmosis.

\section{Conclusions}

The present study concluded that climate, geographical conditions, and age were the major risk factors associated with T. gondii infection in yaks. The results indicate that yaks infected with $T$. gondii are likely to pose a potential threat to humans in the region. This study provides data for the prevention and control of $T$. gondii infection on yak farms on the Qinghai-Tibetan Plateau and the public health threat to local residents and generally in China.

\section{Competing interests}

The authors declare that they have no competing interests.

\section{Funding information}

This study was supported in part by the National Key Research and Development Program of China (Grant No. 2018YFD0502305), National Risk Assessment Project for Quality and Safety of Agricultural Products (Grant No. GJFP2019027), Shanghai Science and Technology Commission Scientific Research Project (Grant No. 20140900400), and Shanghai Agriculture Applied Technology Development Program, China (Grant No. 2019-02-08-00-08-F01151).

Acknowledgements. We thank the local veterinary workers for their help in sample collection.

\section{References}

1. Bigna JJ, Tochie JN, Tounouga DN, Bekolo AO, Ymele NS, Youda EL, Sime PS, Nansseu JR. 2020. Global, regional, and country seroprevalence of Toxoplasma gondii in pregnant women: a systematic review, modelling and meta-analysis. Scientific Report, 10(1), 12102.

2. Boughattas S. 2017. Toxoplasma infection and milk consumption: Meta-analysis of assumptions and evidences. Critical Reviews in Food Science and Nutrition, 57, 2924-2933.

3. da Silva JB, Nicolino RR, Fagundes GM, Dos Anjos Bomjardim H, Dos Santos Belo Reis A, da Silva Lima DH, Oliveira CMC, Barbosa JD, da Fonseca AH. 2017. Serological survey of Neospora caninum and Toxoplasma gondii in cattle (Bos indicus) and water buffaloes (Bubalus bubalis) in ten provinces of Brazil. Comparative Immunology, Microbiology \& Infectious Diseases, 52, 30-35.

4. Dard C, Fricker-Hidalgo H, Brenier-Pinchart MP, Pelloux H. 2016. Relevance of and new developments in serology for toxoplasmosis. Trends in Parasitology, 32, 492-506.

5. Dong H, Su R, Lu Y, Wang M, Liu J, Jian F, Yang Y. 2018. Prevalence, risk factors, and genotypes of Toxoplasma gondii in food animals and humans (2000-2017) from China. Frontiers in Microbiology, 9, 2108. 
6. Dubey JP. 2010. Review of "Toxoplasmosis of animals and humans (Second Edition)". Parasites \& Vectors, 3, 112-112.

7. Dubey JP, Jones JL. 2008. Toxoplasma gondii infection in humans and animals in the United States. International Journal for Parasitology, 38, 1257-1278.

8. Fayer R, Dubey JP, Lindsay DS. 2004. Zoonotic protozoa: from land to sea. Trends in Parasitology, 20, 531-536.

9. Figueiredo JF, Silva DA, Cabral DD, Mineo JR. 2001. Seroprevalence of Toxoplasma gondii infection in goats by the indirect haemagglutination, immunofluorescence and immunoenzymatic tests in the region of Uberlândia, Brazil. Memórias do Instituto Oswaldo Cruz, 96, 687-692.

10. Gao J, Liu M, Meng X, Han Z, Zhang D, Hou B, Zhang K, Sizhu S, Li J. 2013. Seroprevalence of bovine viral diarrhea infection in Yaks (Bos grunniens) on the Qinghai-Tibetan Plateau of China. Tropical Animal Health and Production, 45, 791-793.

11. Holec-Gaôsior L, Drapaõõla D, Dominiak-Górski B, Kur J. 2013. Epidemiological study of Toxoplasma gondii infection among cattle in Northern Poland. Annals of Agricultural and Environmental Medicine, 20, 653-656.

12. Jokelainen P, Tagel M, Mõtus K, Viltrop A, Lassen B. 2017. Toxoplasma gondii seroprevalence in dairy and beef cattle: Large-scale epidemiological study in Estonia. Veterinary Parasitology, 236, 137-143.

13. Khames M, Yekkour F, Fernández-Rubio C, Aubert D, Nguewa P, Villena I. 2018. Serological survey of cattle toxoplasmosis in Medea, Algeria. Veterinary Parasitology: Regional Studies and Reports, 12, 89-90.

14. Khan AA, Slifer T, Araujo FG, Remington JS. 1996. Trovafloxacin is active against Toxoplasma gondii. Antimicrobial Agents and Chemotherapy, 40, 1855-1859.

15. Li K, Gao J, Shahzad M, Han Z, Nabi F, Liu M, Zhang D, Li J. 2014. Seroprevalence of Toxoplasma gondii infection in yaks (Bos grunniens) on the Qinghai-Tibetan Plateau of China. Veterinary Parasitology, 205(1-2), 354-356.

16. Liu J, Cai JZ, Zhang W, Liu Q, Chen D, Han JP, Liu QR. 2008. Seroepidemiology of Neospora caninum and Toxoplasma gondii infection in yaks (Bos grunniens) in Qinghai, China. Veterinary Parasitology, 152, 330-332.

17. Liu Q, Cai J, Zhao Q, Shang L, Ma R, Wang X, Li J, Hu G, Jin H, Gao H. 2011. Seroprevalence of Toxoplasma gondii infection in yaks (Bos grunniens) in northwestern China. Tropical Animal Health and Production, 43, 741-743.

18. Lu Y, Wang G, Cai Q, Ye C, Niu X, Ma L. 2012. Serological investigation of yak toxoplasmosis in cattle farm of Datong, Qinghai Province. Chinese Journal of Animal Health Inspection, 29, 40-41 (in Chinese).

19. Matsuo K, Kamai R, Uetsu H, Goto H, Takashima Y, Nagamune K. 2014. Seroprevalence of Toxoplasma gondii infection in cattle, horses, pigs and chickens in Japan. Parasitology International, 63(4), 638-639.

20. Montoya JG, Liesenfeld O. 2004. Toxoplasmosis. Lancet, 363, 1965-1976.

21. Saad NM, Hussein AAA, Ewida RM. 2018. Occurrence of Toxoplasma gondii in raw goat, sheep, and camel milk in Upper Egypt. Veterinay World, 11, 1262-1265.

22. Sepúlveda-Arias JC, Gómez-Marin JE, Bobić B, Naranjo-Galvis CA, Djurković-Djaković O. 2014. Toxoplasmosis as a travel risk. Travel Medicine and Infectious Disease, 12(6 Pt A), 592-601.

23. Sonda S, Ting L-M, Novak S, Kim K, Maher JJ, Farese RV, Ernst JD. 2001. Cholesterol esterification by host and parasite is essential for optimal proliferation of Toxoplasma gondii. Journal of Biological Chemistry, 276, 34434-34440.

24. Tenter AM, Heckeroth AR, Weiss LM. 2000. Toxoplasma gondii: from animals to humans. International Journal for Parasitology, 30, 1217-1258.

25. Wang ZD, Liu HH, Ma ZX, Ma HY, Li ZY, Yang ZB, Zhu XQ, Xu B, Wei F, Liu Q. 2017. Toxoplasma gondii Infection in immunocompromised patients: A systematic review and metaanalysis. Frontiers in Microbiology, 8, 389.

26. Weiss LM, Dubey JP. 2009. Toxoplasmosis: A history of clinical observations. International Journal for Parasitology, 39, 895-901.

27. Wohlfert EA, Blader IJ, Wilson EH. 2017. Brains and brawn: Toxoplasma infections of the central nervous system and skeletal muscle. Trends in Parasitology, 33, 519-531.

28. Zhang XX, Lou ZZ, Huang SY, Zhou DH, Jia WZ, Su C, Zhu XQ. 2013. Genetic characterization of Toxoplasma gondii from Qinghai vole, Plateau pika and Tibetan ground-tit on the Qinghai-Tibet Plateau, China. Parasites \& Vectors, 6, 291.

Cite this article as: Sun T, Rahman SU, Cai J, Zeng J, Mi R, Zhang Y, Gong H, Ma H, Huang Y, Han X, Zhao Q \& Chen Z. 2021. Seroprevalence and associated risk factors of Toxoplasma gondii infection in yaks (Bos grunniens) on the Qinghai-Tibetan Plateau of China. Parasite 28, 43.

Reviews, articles and short notes may be submitted. Fields include, but are not limited to: general, medical and veterinary parasitology; morphology, including ultrastructure; parasite systematics, including entomology, acarology, helminthology and protistology, and molecular analyses; molecular biology and biochemistry; immunology of parasitic diseases; host-parasite relationships; ecology and life history of parasites; epidemiology; therapeutics; new diagnostic tools.

All papers in Parasite are published in English. Manuscripts should have a broad interest and must not have been published or submitted elsewhere. No limit is imposed on the length of manuscripts.

Parasite (open-access) continues Parasite (print and online editions, 1994-2012) and Annales de Parasitologie Humaine et Comparée (1923-1993) and is the official journal of the Société Française de Parasitologie. 